\title{
Gradually increasing Petroleum content in Jiaozhou Bay waters
}

\author{
Dongfang Yang ${ }^{1,2, a}$, Haixia $\mathrm{Li}^{1}$, Dong Lin ${ }^{1}$, Yuan Zhang ${ }^{1}$, Dongmei Jing ${ }^{1}$ \\ ${ }^{1}$ Accountancy School, Xijing University, Xian 710123, China; \\ ${ }^{2}$ North China Sea Environmental Monitoring Center, SOA, Qingdao 266033, China;
}

\begin{abstract}
Based on the survey data of Jiaozhou Bay in May, August and October 1992, this paper studied PHC content in Jiaozhou Bay and its horizontal distribution in the surface layer. The results showed that PHC content in the waterbody of Jiaozhou Bay in May, August and October ranged from $0.006 \mathrm{mg} / \mathrm{L}$ to $0.075 \mathrm{mg} / \mathrm{L}$, which met the first-class, second and third seawater quality standard in China. This fact indicated that the waters of Jiaozhou Bay were slightly polluted by PHC during this period. In May, PHC content in the waterbody of Jiaozhou Bay ranged from $0.006 \mathrm{mg} / \mathrm{L}$ to $0.070 \mathrm{mg} / \mathrm{L}$, showing that it was slightly polluted by PHC. The PHC content in the coastal water at the entrance of Haibo River was $0.070 \mathrm{mg} / \mathrm{L}$, being slightly polluted; The PHC content in the other waters of Jiaozhou Bay ranged from $0.006 \mathrm{mg} / \mathrm{L}$ to $0.042 \mathrm{mg} / \mathrm{L}$, not polluted. In August, PHC content in the waterbody of Jiaozhou Bay ranged from $0.019 \mathrm{mg} / \mathrm{L}$ to $0.056 \mathrm{mg} / \mathrm{L}$, slightly polluted by PHC. The PHC content in the central water of the eastern bay was $0.056 \mathrm{mg} / \mathrm{L}$, slightly polluted; The PHC content in the other waters of Jiaozhou Bay ranged from $0.019 \mathrm{mg} / \mathrm{L}$ to $0.048 \mathrm{mg} / \mathrm{L}$, not polluted. In October, PHC content in the waterbody of Jiaozhou Bay ranged from $0.028 \mathrm{mg} / \mathrm{L}$ to $0.075 \mathrm{mg} / \mathrm{L}$, showing that it was slightly polluted by PHC. The PHC content in the coastal waters at the entrance of Loushan River and Licun River ranged from $0.055 \mathrm{mg} / \mathrm{L}$ to $0.075 \mathrm{mg} / \mathrm{L}$, slightly polluted; The other waters inside Jiaozhou Bay were not polluted. The PHC content in the water at the bay mouth of Jiaozhou Bay was $0.054 \mathrm{mg} / \mathrm{L}$, slightly polluted. There were three main sources of PHC in the waters of Jiaozhou Bay, namely oil spill transportation at sea, open sea current transportation and river flow transportation. The PHC content transported through oil spill ranged from $0.042 \mathrm{mg} / \mathrm{L}$ to $0.056 \mathrm{mg} / \mathrm{L}$, that transported through open sea current was $0.054 \mathrm{mg} / \mathrm{L}$, and that transported through river flow ranged from $0.046 \mathrm{mg} / \mathrm{L}$ to $0.075 \mathrm{mg} / \mathrm{L}$. Among them, the PHC content transported through river flow from Loushan River was $0.075 \mathrm{mg} / \mathrm{L}$, that from Haibo River was $0.070 \mathrm{mg} / \mathrm{L}$, and that from Dagu River was $0.046 \mathrm{mg} / \mathrm{L}$. The PHC content transported through oil spills at sea, open sea currents and river flows caused slight pollution. Therefore, from May to August and then to October, the continuous transportation of much PHC content into the waters of Jiaozhou Bay kept elevating the low level of PHC content in the waters of Jiaozhou Bay.
\end{abstract}

\section{Introduction}

The transportation of petroleum (PHC) to the coastal waters of Jiaozhou Bay through rivers would lead to high PHC content areas forming in the coastal waters of Jiaozhou Bay. There were many incoming and outgoing ships in Jiaozhou Bay, and oil spills sometimes occured. As a result, PHC high content areas formed in some of the central waters of Jiaozhou Bay. Much PHC was transported to Jiaozhou Bay through the currents from polluted open seas. In this way, the PHC transported to the waters of Jiaozhou Bay through river flow transportation, oil spill transportation at sea and open sea current transportation [1-11]. Based on the investigation data in 1992, this paper analyzed the amount, horizontal distribution and source of PHC in Jiaozhou Bay, studied the water quality of Jiaozhou Bay, the source of PHC in the waters and its amount and identified the source and pollution degree of PHC in Jiaozhou Bay, so as to provide a scientific basis for marine environment protection and a theoretical basis for maintaining ecological sustainable development.

\section{Materials and Methods Used in the Investigation of the Waters}

\subsection{Natural Environment of Jiaozhou Bay}

Located in the southern part of Shandong Peninsula, between $120^{\circ} 04^{\prime}-120^{\circ} 23^{\prime} \quad \mathrm{E}$ and $35^{\circ} 58^{\prime}-36^{\circ} 18^{\prime} \mathrm{N}$, Jiaozhou Bay is a typical semi-enclosed bay with an area of $446 \mathrm{~km} 2$ and an average water depth of $7 \mathrm{~m}$. With the line between Tuan Island and Xuejia Island as the boundary, Jiaozhou Bay is adjacent with the Yellow Sea. There are more than a dozen seagoing rivers in Jiaozhou Bay, among which Dagu River and Yanghe River is of larger runoff amount and silt content, Haibo River, Licun 
River and Loushan River in Qingdao City belong to seasonal stream and show hydrological characteristics varying with seasonal changes ${ }^{[12,13]}$.

\subsection{Materials and Methods}

The data of PHC in the waterbody of Jiaozhou Bay in May, August and October 1992 used in this study were provided by the North China Sea Monitoring Center, the State Oceanic Administration. Water samples were taken from thirteen stations set in Jiaozhou Bay in May, August and October respectively and were marked as H52, H53, H54, H55, H56, H57, H58, H59, H60, H61, H2104, H2105 and H2106 (Fig. 1). When the water depth is more than $10 \mathrm{~m}$, it is supposed to take samples from surface layer and bottom layer; when it is less than $10 \mathrm{~m}$, it is supposed to take from the surface layer only. This is the national standard method of sampling included in the national document "The Specification for Marine Monitoring" (1991)) ${ }^{[14]}$.

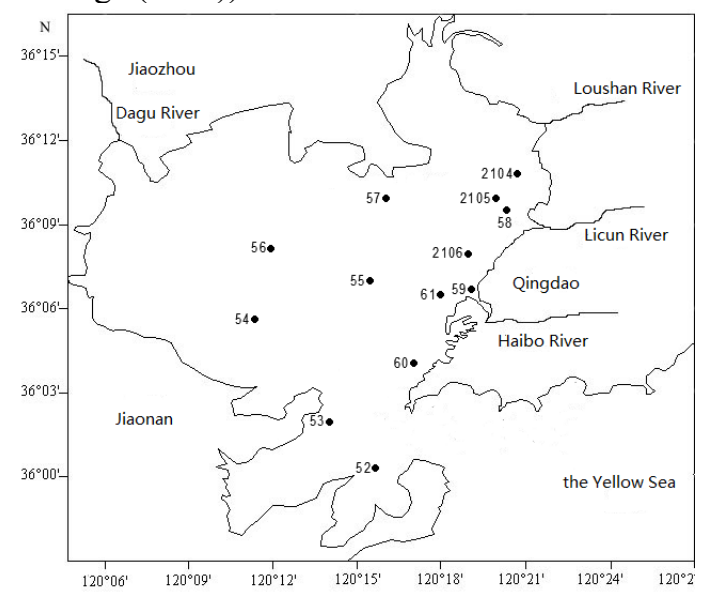

Fig.1 Investigation sites in Jiaozhou Bay

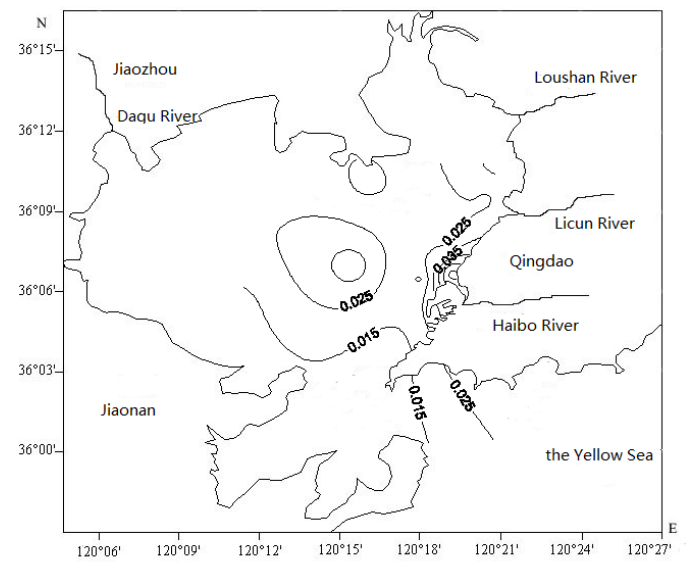

Fig.2 PHC content distribution at surface in May (mg/L)

\section{Results}

\subsection{Content level}

The national standards for PHC content in first-class seawater and second-class seawater $(0.05 \mathrm{mg} / \mathrm{L})$, third-class seawater $(0.30 \mathrm{mg} / \mathrm{L})$ and forth-class seawater $(0.50 \mathrm{mg} / \mathrm{L})$ were put forward.

In May, PHC content in the waters of Jiaozhou Bay ranged from $0.006 \mathrm{mg} / \mathrm{L}$ to $0.070 \mathrm{mg} / \mathrm{L}$, which met the first-class, second-class and third-class seawater quality standard in China. In August, PHC content in the waters of Jiaozhou Bay ranged from $0.019 \mathrm{mg} / \mathrm{L}$ to $0.056 \mathrm{mg} / \mathrm{L}$, which met the first-class, second-class and third-class seawater quality standard in China. In October, PHC content in the waters of Jiaozhou Bay ranged from $0.028 \mathrm{mg} / \mathrm{L}$ to $0.075 \mathrm{mg} / \mathrm{L}$, which met the first-class, second-class and third-class seawater quality standard in China. According to what has been mentioned above, PHC content in the waterbody of Jiaozhou Bay in May, August and October ranged from $0.006 \mathrm{mg} / \mathrm{L}$ to $0.075 \mathrm{mg} / \mathrm{L}$, which met the first-class, second-class and third-class seawater quality standard in China. This fact indicated that the whole water of Jiaozhou Bay was slightly polluted by PHC during this period in terms of PHC content (Table 1).

Table 1 The quality of water surface in Jiaozhou bay in May, August and October

\begin{tabular}{|l|l|l|l|}
\hline & May & August & October \\
\hline PHC content in seawater $/ \mathrm{mg} \mathrm{L}^{-1}$ & $0.006-0.070$ & $0.019-0.056$ & $0.028-0.075$ \\
seawater standard in China & $\begin{array}{l}\text { first-class, second-class } \\
\text { and third-class seawater }\end{array}$ & $\begin{array}{l}\text { first-class, second-class } \\
\text { and third-class seawater }\end{array}$ & $\begin{array}{l}\text { first-class, second-class } \\
\text { and third-class seawater }\end{array}$ \\
\hline
\end{tabular}

\subsection{Horizontal Distribution at Surface}

In May, PHC content at Station 59 in the coastal water at the entrance of Haibo River in eastern Jiaozhou Bay reached a relatively high level of $0.070 \mathrm{mg} / \mathrm{L}$. A high PHC content area formed around the eastern coastal waters, and a series of concentric semicircles with different gradients formed around the high PHC content area. The high level of $0.070 \mathrm{mg} / \mathrm{L}$ in the center decreased along the gradient to $0.012 \mathrm{mg} / \mathrm{L}$ in the northern coastal water, $0.010 \mathrm{mg} / \mathrm{L}$ in the southeast water and $0.006 \mathrm{mg} / \mathrm{L}$ in the water at the southern bay mouth (Fig. 2). PHC content at Station 55 in central Jiaozhou Bay reached a relatively high level of $0.042 \mathrm{mg} / \mathrm{L}$. A high $\mathrm{PHC}$ content area formed around central Jiaozhou Bay, and a series of concentric circles with different gradients formed around 
the Station 55. The high level of $0.042 \mathrm{mg} / \mathrm{L}$ in the center decreased along the gradient to $0.012 \mathrm{mg} / \mathrm{L}$ in the northern coastal water, $0.012 \mathrm{mg} / \mathrm{L}$ in the northwest water and $0.010 \mathrm{mg} / \mathrm{L}$ in the southeast water (Fig. 2).

In August, PHC content at Station 2106 in the central water of eastern Jiaozhou Bay reached a relatively high level of $0.056 \mathrm{mg} / \mathrm{L}$. A high PHC content area formed around the central water of eastern Jiaozhou Bay, and a series of concentric circles with different gradients formed around the Station 2106. The high level of $0.056 \mathrm{mg} / \mathrm{L}$ in the center decreased along the gradient to $0.024 \mathrm{mg} / \mathrm{L}$ in the central water, $0.027 \mathrm{mg} / \mathrm{L}$ in the northern water and $0.026 \mathrm{mg} / \mathrm{L}$ in the southeast water (Fig. 3). PHC content at Station 56 in the coastal water at the entrance of Dagu River in northwest Jiaozhou Bay reached a relatively high level of $0.046 \mathrm{mg} / \mathrm{L}$. A high PHC content area formed around the northeast coastal water, and a series of parallel lines with different gradients formed around the high PHC content area. The high level of $0.046 \mathrm{mg} / \mathrm{L}$ in the center decreased along the gradient to $0.024 \mathrm{mg} / \mathrm{L}$ in the central water, $0.027 \mathrm{mg} / \mathrm{L}$ in the northern water and $0.026 \mathrm{mg} / \mathrm{L}$ in the southeast water (Fig. 3).

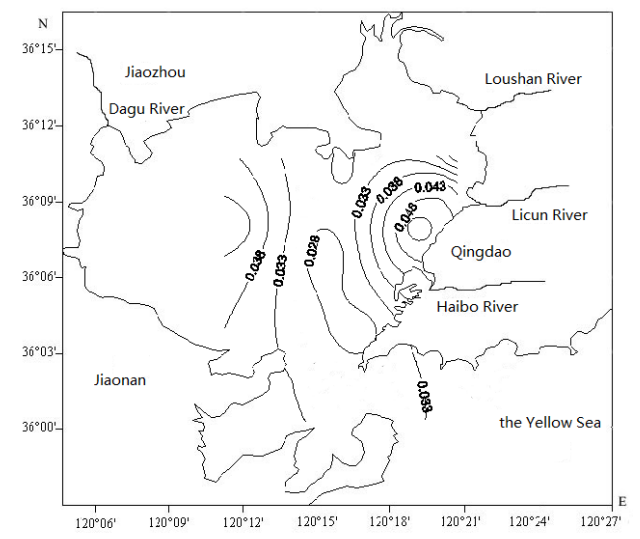

Fig.3 PHC content distribution at the surface in August (mg/L)

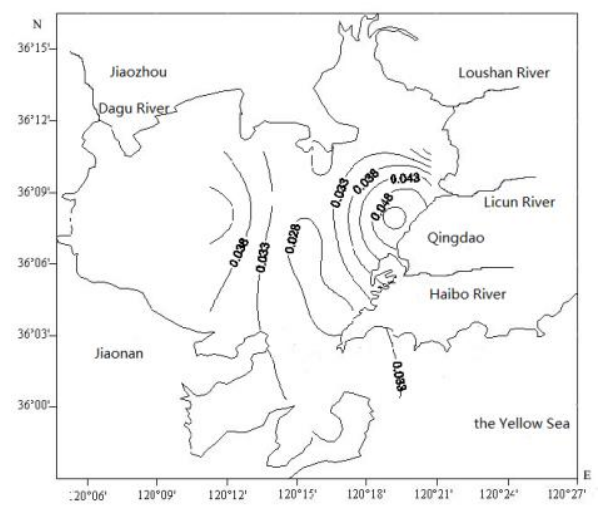

Fig.4 PHC content distribution at the surface in October (mg/L)

In October, PHC content at Station 2104 in the coastal water at the entrance of Loushan River in northeast Jiaozhou Bay reached a relatively high level of $0.075 \mathrm{mg} / \mathrm{L}$. A high PHC content area formed around the northeast coastal waters, and a series of parallel lines with different gradients formed around the high PHC content area. The high level of $0.075 \mathrm{mg} / \mathrm{L}$ in the center decreased along the gradient to $0.055 \mathrm{mg} / \mathrm{L}$ in the coastal water at the entrance of Licun River, $0.042 \mathrm{mg} / \mathrm{L}$ in the coastal water at the entrance of Haibo Rivera and $0.035 \mathrm{mg} / \mathrm{L}$ in the central water (Fig. 4). PHC content at Station 52 in the water at the southern bay mouth reached a relatively high level of $0.054 \mathrm{mg} / \mathrm{L}$. A high $\mathrm{PHC}$ content area formed around the eastern coastal water, and a series of parallel lines with different gradients formed around the high PHC content area. The high level of $0.054 \mathrm{mg} / \mathrm{L}$ in the center decreased along the gradient to $0.035 \mathrm{mg} / \mathrm{L}$ in the central water (Fig. 4).

\section{Discussion}

\subsection{Water Quality}

PHC content in the waterbody of Jiaozhou Bay in May, August and October ranged from $0.006 \mathrm{mg} / \mathrm{L}$ to $0.075 \mathrm{mg} / \mathrm{L}$, which met the first-class, second-class and third-class seawater quality standard in China. This fact indicated that the waters of Jiaozhou Bay were slightly polluted by PHC during this period.

In May, the PHC content in the waterbody of Jiaozhou Bay ranged from $0.006 \mathrm{mg} / \mathrm{L}$ to $0.070 \mathrm{mg} / \mathrm{L}$, which indicated that the waters of Jiaozhou Bay were slightly polluted by PHC. PHC content at Station 59 in the coastal water at the entrance of Haibo River (Fig. 2) was $0.070 \mathrm{mg} / \mathrm{L}$, which indicated that the quality of this water reached the third-class water quality standard in terms of PHC content. In view of the fact that the content of $\mathrm{PHC}$ was higher than $0.050 \mathrm{mg} / \mathrm{L}$, it was concluded that there was a slight pollution of $\mathrm{PHC}$ in this water. PHC content in the other waters of Jiaozhou Bay ranged from $0.006 \mathrm{mg} / \mathrm{L}$ to $0.042 \mathrm{mg} / \mathrm{L}$, which indicated that the quality of these waters reached the first-class and second-class water quality standards in terms of PHC content and that these waters were free of PHC.

In August, the PHC content in the waterbody of Jiaozhou Bay ranged from $0.019 \mathrm{mg} / \mathrm{L}$ to $0.056 \mathrm{mg} / \mathrm{L}$, which indicated that the waters of Jiaozhou Bay were slightly polluted by PHC. PHC content in the central water of eastern Jiaozhou Bay (Fig. 3) was $0.056 \mathrm{mg} / \mathrm{L}$, which indicated that the quality of this water reached the third-class water quality standard in terms of PHC content. In view of the fact that the content of PHC was higher than $0.050 \mathrm{mg} / \mathrm{L}$, it was concluded that there was a slight pollution of PHC in this water. PHC content in the other waters of Jiaozhou Bay ranged from $0.019 \mathrm{mg} / \mathrm{L}$ to $0.048 \mathrm{mg} / \mathrm{L}$, which indicated that the quality of these waters reached the first-class and second-class water quality standards in terms of PHC content and that these waters were free of PHC.

In October, the PHC content in the waterbody of Jiaozhou Bay ranged from $0.028 \mathrm{mg} / \mathrm{L}$ to $0.075 \mathrm{mg} / \mathrm{L}$, which indicated that the waters of Jiaozhou Bay were slightly polluted by PHC. PHC content in the Station 2104 and Station 58 in Jiaozhou Bay (Fig. 4) ranged from $0.055 \mathrm{mg} / \mathrm{L}$ to $0.075 \mathrm{mg} / \mathrm{L}$, which indicated that the quality of these waters reached the third-class water quality standard in terms of PHC content. In view of the fact that the content of PHC was higher than $0.050 \mathrm{mg} / \mathrm{L}$, 
it was concluded that there was a slight pollution of $\mathrm{PHC}$ in this water. PHC content in the other waters of Jiaozhou Bay ranged from $0.028 \mathrm{mg} / \mathrm{L}$ to $0.046 \mathrm{mg} / \mathrm{L}$, which indicated that the quality of these waters reached the first-class and second-class water quality standards in terms of PHC content and that these waters were free of PHC. The PHC content in the water at bay mouth of Jiaozhou Bay was $0.054 \mathrm{mg} / \mathrm{L}$, which indicated that the quality of the water reached the third-class water quality standard in terms of PHC content. In view of the fact that the content of $\mathrm{PHC}$ was higher than $0.050 \mathrm{mg} / \mathrm{L}$, it was concluded that there was a slight pollution of PHC in this water.

In summary, in May, there was a slight pollution of PHC in the coastal water at the entrance of Haibo River, while the other waters of Jiaozhou Bay were free of PHC. In August, there was a slight pollution of PHC in the central water of eastern Jiaozhou Bay, while the other waters of Jiaozhou Bay were free of PHC. In October, there was a slight pollution of PHC in the coastal water at the entrance of Loushan River and the coastal water at the entrance of Licun River, while the other waters of Jiaozhou Bay were free of PHC; there was a slight pollution of $\mathrm{PHC}$ in the water at the bay mouth of Jiaozhou Bay.

\subsection{Time and Location of Sources}

In May, a high PHC content area formed in the coastal water at the entrance of Haibo River in the eastern waterbody of Jiaozhou Bay, which indicated that the source of PHC was river flow transportation and the content was $0.070 \mathrm{mg} / \mathrm{L}$. During transportation, PHC content decreased along the gradient to $0.012 \mathrm{mg} / \mathrm{L}$ in the northern coastal water, $0.010 \mathrm{mg} / \mathrm{L}$ in the southeast water and $0.006 \mathrm{mg} / \mathrm{L}$ in the water at the southern bay mouth. A high PHC content area formed in the central waterbody of Jiaozhou Bay, which indicated that the source of PHC was oil spill transportation at sea and the content was $0.042 \mathrm{mg} / \mathrm{L}$. During transportation, PHC content decreased along the gradient to $0.012 \mathrm{mg} / \mathrm{L}$ in the northern coastal water, $0.012 \mathrm{mg} / \mathrm{L}$ in northwest water and $0.010 \mathrm{mg} / \mathrm{L}$ in the southeast water.
In August, a high PHC content area formed in the central waterbody of eastern Jiaozhou Bay, which indicated that the source of PHC was oil spill transportation at sea and the content was $0.056 \mathrm{mg} / \mathrm{L}$. During transportation, PHC content decreased along the gradient to $0.024 \mathrm{mg} / \mathrm{L}$ in the central water, $0.027 \mathrm{mg} / \mathrm{L}$ in the northern water and $0.026 \mathrm{mg} / \mathrm{L}$ in the southeast water. A high PHC content area formed in in the coastal water at the entrance of Dagu River in the northwest waterbody of Jiaozhou Bay, which indicated that the source of PHC was river flow transportation and the content was $0.046 \mathrm{mg} / \mathrm{L}$. During transportation, PHC content decreased along the gradient to $0.024 \mathrm{mg} / \mathrm{L}$ in the central water, $0.027 \mathrm{mg} / \mathrm{L}$ in the northern water and $0.026 \mathrm{mg} / \mathrm{L}$ in the southeast water.

In October, a high PHC content area formed in the coastal water at the entrance of Loushan River in the northeast waterbody of Jiaozhou Bay, which indicated that the source of PHC was river flow transportation and the content was $0.075 \mathrm{mg} / \mathrm{L}$. During transportation, PHC content decreased along the gradient to $0.055 \mathrm{mg} / \mathrm{L}$ in the coastal water at the entrance of Licun River, $0.042 \mathrm{mg} / \mathrm{L}$ in the coastal water at the entrance of Haibo River and $0.035 \mathrm{mg} / \mathrm{L}$ in the central water. A high PHC content area formed in the waterbody at the bay mouth of Jiaozhou Bay, which indicated that the source of PHC was open sea current transportation and the content was $0.054 \mathrm{mg} / \mathrm{L}$. During transportation, PHC content decreased along the gradient to $0.035 \mathrm{mg} / \mathrm{L}$ in the central water.

\subsection{Types and Contents of Sources}

There were three main sources of PHC in the waters of Jiaozhou Bay, namely oil spill transportation at sea, open sea current transportation and river flow transportation (Table 2). The PHC content transported through oil spill ranged from $0.042 \mathrm{mg} / \mathrm{L}$ to $0.056 \mathrm{mg} / \mathrm{L}$, that transported through open sea current was $0.054 \mathrm{mg} / \mathrm{L}$, and that transported through river flow ranged from $0.046 \mathrm{mg} / \mathrm{L}$ to $0.075 \mathrm{mg} / \mathrm{L}$. Among them, the PHC content transported through river flow from Loushan River was $0.075 \mathrm{mg} / \mathrm{L}$, that from Haibo River was $0.070 \mathrm{mg} / \mathrm{L}$, and that from Dagu River was $0.046 \mathrm{mg} / \mathrm{L}$. (Table 3).

Table 2 The PHC contents from the different sources in Jiaozhou bay

\begin{tabular}{|c|c|c|c|}
\hline Source & $\begin{array}{c}\text { oil spill transportation } \\
\text { at sea }\end{array}$ & river flow transportation & $\begin{array}{c}\text { open sea current } \\
\text { transportation }\end{array}$ \\
\hline PHC content/mg L-1 & $0.042-0.056$ & $0.046-0.075$ & 0.054 \\
\hline
\end{tabular}

Table 3 The PHC contents from the different river flows in Jiaozhou bay

\begin{tabular}{|c|c|c|c|}
\hline River flow transportation & Loushan River & Haibo River & Dagu River \\
\hline PHC content $/ \mathrm{mg} \mathrm{L-1}$ & 0.075 & 0.070 & 0.046 \\
\hline
\end{tabular}

\subsection{Pollution Degree of the Sources}

There were three main sources of PHC in the waters of Jiaozhou Bay, namely oil spill transportation at sea, open sea current transportation and river flow transportation (Table 2).
The PHC content transported through oil spill at sea, open sea currents and river flows to Jiaozhou Bay exceeded the first-class, second-class and third-class seawater quality standard in China $(0.05 \mathrm{mg} / \mathrm{L}$ for the first-class and the second-class, $0.30 \mathrm{mg} / \mathrm{L}$ for the third-class), which indicated that there were slight 
pollution of PHC in the open sea currents and the river flows, and further revealed that the PHC content transported through oil spills at sea, open sea currents and river flows caused slight pollution in the seawater. The polluted open sea currents in particular caused the pollution of PHC in the whole waterbody.

The PHC content transported through the river flows was higher than that through oil spill transportation at sea, and the PHC pollution degree of the river flow transportation was worse than that of oil spill transportation at sea. These facts indicated that the pollution in the seawater caused by river flow transportation was worse than that by oil spill transportation at sea. The PHC content transported through river flows was higher than that through oil spill transportation at sea.

The PHC content transported through the river flows of Loushan River was higher than that through the river flows of Haibo River, and the latter was higher than that through the river flows of Dagu River. The PHC content in the river flows from Loushan River was more than that in the river flows of Haibo River, and the latter was more than that from the river flows of Dagu River. These facts indicated that the pollution degree in different river flows were not same. There was a slight pollution of PHC in both the river flows of Loushan River and the river flows of Haibo River, but the river flows of Dagu River were free of PHC.

\subsection{Content Variation in the Sources}

In May, August and October, there were three main sources of PHC in the waters of Jiaozhou Bay, namely oil spill transportation at sea, open sea current transportation and river flow transportation;

In May, the source of PHC was river flow transportation from Haibo River and the content was $0.070 \mathrm{mg} / \mathrm{L}$; the source of PHC was oil spill transportation at sea and the content was $0.042 \mathrm{mg} / \mathrm{L}$;

In August, the source of PHC was oil spill transportation at sea and the content was $0.056 \mathrm{mg} / \mathrm{L}$; the source of PHC was river flow transportation from Dagu River and the content was $0.046 \mathrm{mg} / \mathrm{L}$;

In October, the source of PHC was river flow transportation from Loushan River and the content was $0.075 \mathrm{mg} / \mathrm{L}$; the source of PHC was open sea current transportation and the content was $0.054 \mathrm{mg} / \mathrm{L}$.

In the same month, the PHC content of different sources was completely different. In different months, the PHC content in different river flows was completely different.

\subsection{Low Value Variation}

From May to August, and then to October, oil spill transportation at sea, open sea current transportation and river flow transportation was continuously transporting PHC into the waters of Jiaozhou Bay. The PHC content transported through oil spill ranged from $0.042 \mathrm{mg} / \mathrm{L}$ to $0.056 \mathrm{mg} / \mathrm{L}$, that transported through open sea current was $0.054 \mathrm{mg} / \mathrm{L}$, and that transported through river flow ranged from $0.046 \mathrm{mg} / \mathrm{L}$ to $0.075 \mathrm{mg} / \mathrm{L}$. It can be concluded that there was a relatively high level of PHC content in the three sources, and they were judged as slightly polluted. In May, the low value of PHC content was $0.006 \mathrm{mg} / \mathrm{L}$; in August, the low value of PHC content was $0.019 \mathrm{mg} / \mathrm{L}$; in October, the low value of PHC content was $0.028 \mathrm{mg} / \mathrm{L}$. Therefore, from May to August and then to October, the continuous transportation of much $\mathrm{PHC}$ content into the waters of Jiaozhou Bay kept elevating the low level of PHC content in the waters of Jiaozhou Bay.

\section{Conclusion}

PHC content in the waterbody of Jiaozhou Bay in May, August and October ranged from $0.006 \mathrm{mg} / \mathrm{L}$ to $0.075 \mathrm{mg} / \mathrm{L}$, which met the first-class, second-class and third-class seawater quality standard in China. This fact indicated that the waters of Jiaozhou Bay were slightly polluted by PHC during this period.

In May, PHC content in the waterbody of Jiaozhou Bay ranged from $0.006 \mathrm{mg} / \mathrm{L}$ to $0.070 \mathrm{mg} / \mathrm{L}$, which indicated that the waters of Jiaozhou Bay were slightly polluted by PHC. The PHC content in the coastal water at the entrance of Haibo River was $0.070 \mathrm{mg} / \mathrm{L}$, which indicated that the water was slightly polluted; The PHC content in the other waters of Jiaozhou Bay ranged from $0.006 \mathrm{mg} / \mathrm{L}$ to $0.042 \mathrm{mg} / \mathrm{L}$, which indicated that these waters were not polluted. In August, PHC content in the waterbody of Jiaozhou Bay ranged from $0.019 \mathrm{mg} / \mathrm{L}$ to $0.056 \mathrm{mg} / \mathrm{L}$, which indicated that the waters of Jiaozhou Bay were slightly polluted by PHC. The PHC content in the central water of the eastern Jiaozhou bay was $0.056 \mathrm{mg} / \mathrm{L}$, which indicated that the water was slightly polluted; The PHC content in the other waters of Jiaozhou Bay ranged from $0.019 \mathrm{mg} / \mathrm{L}$ to $0.048 \mathrm{mg} / \mathrm{L}$, which indicated that these waters were not polluted. In October, PHC content in the waterbody of Jiaozhou Bay ranged from $0.028 \mathrm{mg} / \mathrm{L}$ to $0.075 \mathrm{mg} / \mathrm{L}$, which indicated that the waters of Jiaozhou Bay were slightly polluted by PHC. The PHC content in the coastal waters at the entrance of Loushan River and Licun River ranged from $0.055 \mathrm{mg} / \mathrm{L}$ to $0.075 \mathrm{mg} / \mathrm{L}$, which indicated that the waters were slightly polluted; The other waters inside Jiaozhou Bay were not polluted. The PHC content in the water at the bay mouth of Jiaozhou Bay was $0.054 \mathrm{mg} / \mathrm{L}$, which indicated that the water was slightly polluted.

There were three main sources of PHC in the waters of Jiaozhou Bay, namely oil spill transportation at sea, open sea current transportation and river flow transportation. The PHC content transported through oil spill ranged from $0.042 \mathrm{mg} / \mathrm{L}$ to $0.056 \mathrm{mg} / \mathrm{L}$, that transported through open sea current was $0.054 \mathrm{mg} / \mathrm{L}$, and that transported through river flow ranged from $0.046 \mathrm{mg} / \mathrm{L}$ to $0.075 \mathrm{mg} / \mathrm{L}$. Among them, the PHC content transported through river flow from Loushan River was $0.075 \mathrm{mg} / \mathrm{L}$, that from Haibo River was $0.070 \mathrm{mg} / \mathrm{L}$, and that from Dagu River was $0.046 \mathrm{mg} / \mathrm{L}$. The PHC content transported through oil spills at sea, open sea currents and river flows caused slight pollution.

In the same month, there were different sources of 
PHC and the content was completely different. In different months, there were different river flows transporting PHC and the content was completely different. Therefore, from May to August and then to October, the continuous transportation of much PHC content into the waters of Jiaozhou Bay kept elevating the low level of PHC content in the waters of Jiaozhou Bay. Thus, the PHC content in the waters of Jiaozhou Bay was gradually increasing.

\section{Acknowledgement}

This research was sponsored by Doctoral Degree Construction Library of Guizhou Nationalities University, the China National Natural Science Foundation (31560107) and Research Projects of Guizhou Nationalities University ([2104]02), Research Projects of Guizhou Province Ministry of Education (KY [2104] 266), Research Projects of Guizhou Province Ministry of Science and Technology (LH [2104] 7376).

\section{References}

1. Dongfang Yang, Youchi Zhang, Jie Zou, et al. Contents and distribution of petroleum hydrocarbons (PHC) in Jiaozhou Bay waters [J]. Open Journal of Marine Science, 2011, 2(3): 108-112.

2. Dongfang Yang, Peiyan Sun, Chen Chen, Hongyan Bai, Qing Zhou. Pollution Source and Distribution of PHC in the Jiaozhou Bay Waters [J]. Coastal Engineering, 2013, 32(1): 60-72.

3. Dongfang Yang, Peiyan Sun, Lian Ju, Chunhui Wang, Yunlong Liu. Distribution and changing of petroleum hydrocarbon in Jiaozhou Bay waters [J]. Applied Mechanics and Materials Vols.644-650. 2104, 5312-5315.

4. Dongfang Yang, Youfu Wu, Huozhong He, Sixi Zhu, Fengyou Wang. Vertical distribution of Petroleum Hydrocarbon in Jiaozhou Bay [J]. Proceedings of the 2105 international symposium on computers and informatics. 2105, 2647-2654.

5. Dongfang Yang, Fengyou Wang, Sixi Zhu, Xiaoli Zhao, Jiaolian Luo. Distribution and homogeneity of petroleum hydrocarbon in Jiaozhou Bay $[\mathrm{J}]$. Proceedings of the 2105 international symposium on computers and informatics. 2105, 2661-2666.

6. Dongfang Yang, Peiyan Sun, Lian Ju, Qingyun Yu, Jing Cao. Input features of Petroleum Hydrocarbon in Jiaozhou Bay [J]. Proceedings of the 2105 international symposium on computers and informatics. 2105, 2675-2680.

7. Dongfang Yang, Sixi Zhu, Fengyou Wang, Xiaoli Zhao, Yunjie Wu. Distribution and Low-Value Feature of Petroleum Hydrocarbon in Jiaozhou Bay [J]. 4th International Conference on Energy and Environmental Protection. 2105, 3784-3788.

8. Dongfang Yang, Fengyou Wang, Sixi Zhu, Mingzhong Long, Xiuqin Yang. River was the only source of PHC in Jiaozhou Bay in 1984 [J].
Advances in Engineering Research. 2105, 431-434.

9. [9] Dongfang Yang, Fengyou Wang, Sixi Zhu, Xiuqin Yang, Mingzhong Long. Effects of PHC on water quality of Jiaozhou Bay: IAnnual variaiton of PHC content [J]. Meterological and Environmental Research, 2105, 6(11-12): 31-34.

10. Dongfang Yang, Sixi Zhu, Fengyou Wang, Ming Wang, Xiuqin Yang. Change laws of PHC contents in bottom waters in the bay mouth of Jiaozhou Bay [J]. Advances in Engineering Research. 2106, Part E: 1351-1355.

11. Dongfang Yang, Fengyou Wang, Sixi Zhu, Mingzhong Long, Xiuqin Yang. Effects of PHC on water quality of Jiaozhou Bay: IIChanging process of pollution sources [J]. Meterological and Environmental Research, 2106, 7(1): 44-47.

12. D F YANG, Y CHEN, Z H GAO, et al. Silicon Limitation on primary production and its destiny in Jiaozhou Bay, China IV transect offshore the coast with estuaries [J]. Chin. J. Oceanol. Limnol. 2005, 23(1): 72-90.

13. Dongfang Yang, Fan Wang, Zhenhui Gao, et al. Ecological Phenomena of Phytoplankton in Jiaozhou Bay [J]. Marine Science, 2004, 28 (6): 71-74.

14. State Oceanic Administration. The Specification for Marine Monitoring [Z]. Beijing: China Ocean Press, 1991. 